\title{
Determination of Accuracy at Backpropagation Method in Prediction Crude Oil Prices
}

\author{
Jhon Veri, Surmayanti Surmayanti, Guslendra Guslendra \\ Universitas Putra Indonesia YPTK Padang, Sumatera Barat, Indonesia
}

\begin{abstract}
We analyzed the performance of the artificial neural network with the backpropagation method in predicting crude oil prices in this paper, including the case of crude oil price predictions. The training results obtained that the MSE value was 0.00099762 with 135 Epoch, in the network testing the MSE value was 0.093336. Meanwhile, the predicted value is determined by the target value with a contribution of $99 \%$ with a significant effect. Thus the accuracy level is determined by the target value and the predicted value. The accuracy of the system is obtained for $83,6 \%$.
\end{abstract}

Keywords - Backpropagation, Accuracy, Prediction.

\section{Introduction}

Crude oil is one of the main energy sources which is most widely used in almost all countries. Every country will need oil for various activities including consumption and production in order to drive the economy, such as increasing productivity in the industrial and transportation sectors [1]. As we know, oil prices in Indonesia are very volatile and tend to increase.

DOI: 10.18421/SAR44-05

https://doi.org/10.18421/SAR44-05

Corresponding author: Jhon Veri, Universitas Putra Indonesia YPTK Padang,

Sumatera Barat, Indonesia.

Email: jhon@upiyptk.ac.id

Received: 17 November 2021.

Revised: 16 December 2021.

Accepted: 20 December 2021.

Published: 27 December 2021.

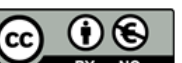

(C) 2021 Jhon Veri, Surmayanti Surmayanti

\& Guslendra Guslendra; published by UIKTEN. This work is licensed under the CC BY-NC 4.0.

The article is published with Open Access at www.sarjournal.com
The increasing price of oil is, of course, the concern of almost all countries in the world, both producing (exporting) oil and consuming (importing) countries. This is due to the role of crude oil in driving the economy. Crude oil is a commodity that plays a vital role in all economic activities. In 2015 the Indonesian Government decided to revoke the fuel subsidy fund, which means that the World Crude Oil Price will directly affect the price of fuel. The direct impact when BBM is non-subsidized is the change in operating costs which results in a corrected rate of return on investment activities. In the APBNP 2011 the price of Indonesian crude oil was set at USD 95 per barrel, however, between January to December 2011 the average ICP realization was USD 111.55 per barrel or $17.42 \%$ higher than the estimates in the APBN- P 2011. ICP had reached USD 123 per barrel in April 2011, then declined again and was in the range of USD 109-117 per barrel [2]. In addition to fundamental factors such as the existence of extreme winters in Europe and America, the decline in US crude oil stocks, the interruption of oil supply from the Trans-Alaska pipeline due to leaks, geopolitical factors such as the political crisis in the Middle East and the fall of Gaddafi in Libya also affected the increase oil prices as well as the economic crisis that hit Europe and America (ESDM, 2012). Predictions can be calculated using various methods. One of the prediction methods that are often used and developed today is backpropagation. Although it has several weaknesses such as inconsistent training results and it is not known in detail how the predicted results are obtained, and this method cannot provide information about the most influential weights among the input patterns, this method also has advantages. The advantage of this method is that it is able to formulate the experience and knowledge of forecasters, and is very flexible in changing forecast rules [3]. Artificial Neural Networks have been fairly reliable over the last few years in problem solving. Neural networks provide a very reliable methodology in solving non-linear problems. Artificial neural networks are inspired by the human brain in which neurons are non-linearly interconnected. Neurons are connected to each other through a network. This 
network is trained using the backpropagation algorithm that follows the Gradient Descent Method [4]. Backpropagation is an Artificial Neural Network architecture that has a forward learning process and backward error correction. This model is widely used for both recognition and prediction processes with a fairly good level of accuracy [3].

\section{Literature Review}

Neural Networks is an information processing paradigm inspired by the biological nervous system, such as the processing of information in the human brain. The key element of this paradigm is the structure of the information processing system which consists of a large number of interconnected processing elements (neurons), working simultaneously to solve a particular problem [5]. The way ANN works is like how humans work, namely learning by example. The layers of ANN are divided into 3, namely the input layer (input layer), the hidden layer (hidden layer), and the output layer (output layer) [6]. Single layer neural networks have limitations in pattern recognition. This drawback can be overcome by adding one or more hidden layers between the input layer and the output layer. Backpropagation Artificial Neural Network (ANNBP) trains the network to find a balance between the network's ability to recognize patterns used during training and the ability to respond correctly to input patterns similar to the patterns used during training [7]. Basically, ANN is a system that accepts input, processes data, and then provides output related to the input. The advantage of ANN is that it can be used to retrieve data, detect trends, and can also predict patterns that are not provided during training which is called generalization [4].

\section{Research Method}

This study aims to analyze the performance of the backpropagation method of neural networks in predicting crude oil prices. The author wants to know how the backpropagation method neural network performance in recognizing patterns in predicting crude oil prices. Forecasting techniques are widely used for planning and decision-making processes. A forecast tries to predict what will happen and what will be the needs. In Artificial Neural Networks, there is a predictive technique that is often used, namely backpropagation. This technique is usually used in multi-layer networks with the aim of minimizing the error in the output generated by the network [8]. To achieve this goal, the authors will conduct training and data testing using crude oil price data for 2018 - 2020. Predictions of crude oil prices with the backpropagation neural network are used as follows:

a. Separating the data that will be used as training data and test data. Crude oil price data for 2018-
2019 will be used as training data during the design of Artificial Neural Networks, while data for 2020 is used as testing data.

b. Neural Network Design is carried out to predict the price of crude oil starting by determining the amount of input data used, the number of hidden screens used, and the number of outputs desired. To find out the price of crude oil in 2021, the input data is the input data including the period of 2018 - 2020 with a target of 2021 in Indonesia.

c. Pattern recognition (training) is done by adjusting the weight value (in this study the weight value is determined randomly). The weight adjustment stops in pattern recognition when the error square reaches the target error. The error is calculated after the forward propagation stage. If the error is greater than the target error, the training will continue to the backward propagation stage until the error reaches or is less than the target error.

d. Testing and prediction. Testing is carried out aiming to determine the level of accuracy of the Artificial Neural Network system that has been made in predicting crude oil prices in a certain year. Meanwhile, the prediction aims to predict future crude oil prices.

\section{Result and Discussion}

This study uses a scenario by combining hidden neurons with alpha. The value of hidden neurons used is 6-12, while the learning rate values tested are 0.1 - 0.9. Epoch 10000 and error tolerance 0.001. Based on the experimental results of the combination of alpha and hidden neurons above, the smallest MSE value is obtained in the combination of training variables alpha 0.5 and hidden neuron 12 , so this combination is used as a variable combination for the next process, namely the process of predicting the effect of alpha and hidden neurons against MSE training and MSE testing. That the MSE value of training will be lower along with the increase in alpha value and the number of hidden neurons. The alpha value affects the MSE value of training. This is because the function of the alpha value is to accelerate convergence. This convergence affects the resulting output value, if the convergence value is reached, the difference between the output value and the actual data will be slightly different or even the value can be the same so that the resulting training MSE value will be lower. While the number of hidden neurons has an effect on the resulting error, the greater the number of hidden neurons, the smaller the resulting error [9]. Regarding the effect of alpha and hidden neurons on the value of MSE training and MSE testing, it can be concluded that there is no constant correlation between alpha and total hidden neurons with the MSE value. The combination of training variables, the amount of data and initialization of the initial network weight will result 
in the lowest MSE value obtained at the alpha value and the number of hidden neurons that are not always the same. The combination of variables that have been generated from previous experiments will then be carried out by testing the accuracy of the system.

$$
\text { MAPE }=\sum_{\mathrm{t}=1}^{\mathrm{n}}\left|\frac{y_{i}-\widehat{y}_{i}}{\hat{y}_{i}}\right| \times 100 \%
$$

Mean Absolute Percentage Error (MAPE) is to provide information on how much the forecasting error is compared to the actual value of the series. Accuracy $=100 \%-\mathrm{MAPE}=100 \%-16,40 \%=83,6 \%$ The accuracy of the system is obtained for $83,6 \%$. To see how much influence normalized crude oil data has on the target $(\mathrm{Y})$, can be explained in the processing results using the following SPSS 15.0:

\section{Table.4.1. Normalized Training Data}

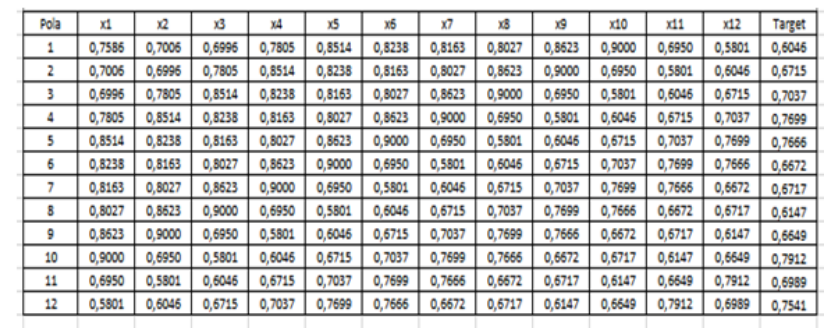

Table.4.2. Normalized Testing Data
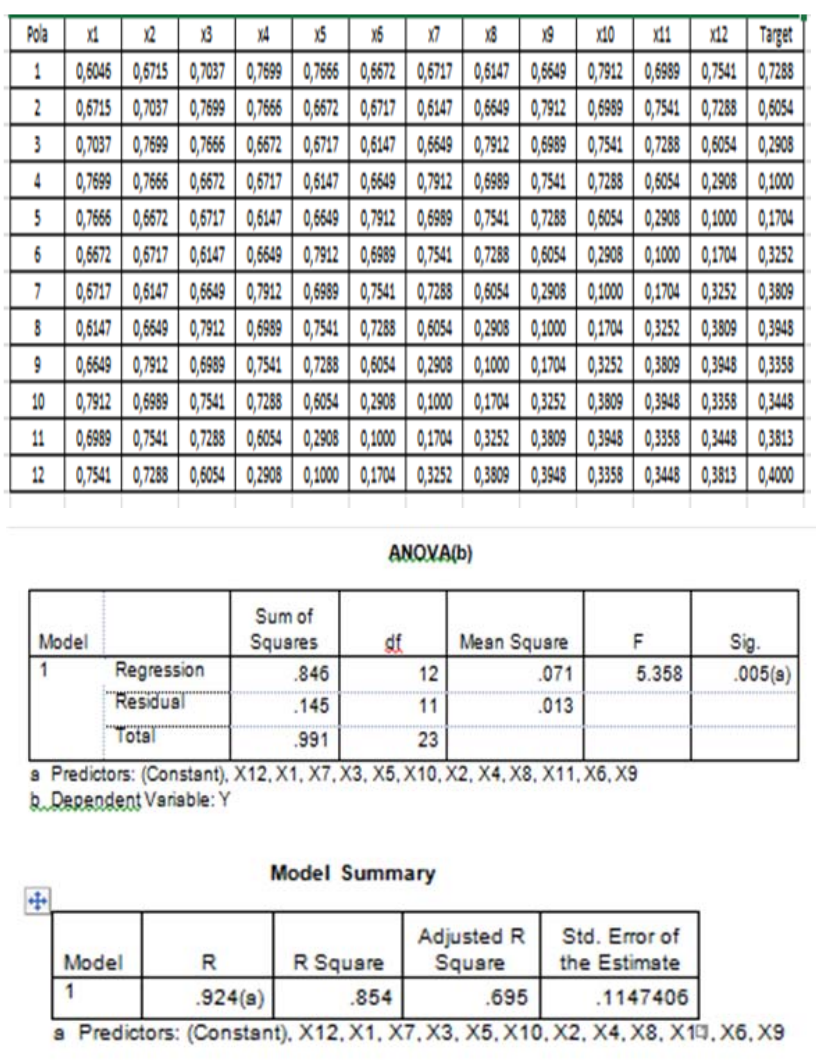

The results explained that the contribution of the crude oil data variable to the target variable was
$85.4 \%$, while the remaining $14.6 \%$ was determined by variables outside the data studied, and to see the effect of the crude oil data variable on the target variable was significant because of sig. $<0.05$ This means that in research, crude oil data can be used to predict the price of crude oil against the target variable. Meanwhile, the relationship between MSE (training) and MSE (testing), can be seen from the results of the following SPSS 15.0 data processing:

Table.4.3. MSE Training and MSE Testing

\begin{tabular}{|c|c|c|c|c|c|}
\hline NO. & $\begin{array}{c}\text { MSE } \\
\text { (Training) }\end{array}$ & $\begin{array}{c}\text { MSE } \\
\text { (Testing) }\end{array}$ & NO. & $\begin{array}{c}\text { MSE } \\
\text { (Training) }\end{array}$ & $\begin{array}{c}\text { MSE } \\
\text { Testing) }\end{array}$ \\
\hline 1 & 0.00099966 & 0.095934 & 33 & 0.00098720 & 0.087814 \\
\hline 2 & 0.00099979 & 0.095963 & 34 & 0.00097482 & 0.079383 \\
\hline 3 & 0.00099996 & 0.095631 & 35 & 0.00099140 & 0.083805 \\
\hline 4 & 0.00099968 & 0.096132 & 36 & 0.00099636 & 0.082229 \\
\hline 5 & 0.00099677 & 0.097315 & 37 & 0.00099762 & 0.093336 \\
\hline 6 & 0.00099984 & 0.095819 & 38 & 0.00099978 & 0.093939 \\
\hline 7 & 0.00099989 & 0.096108 & 39 & 0.00098065 & 0.089639 \\
\hline 8 & 0.0009999 & 0.096761 & 40 & 0.00098517 & 0.093627 \\
\hline 9 & 0.00099971 & 0.095584 & 41 & 0.00097729 & 0.094889 \\
\hline 10 & 0.00099263 & 0.063095 & 42 & 0.00099427 & 0.093999 \\
\hline 11 & 0.00099939 & 0.062034 & 43 & 0.00099997 & 0.094864 \\
\hline 12 & 0.00095831 & 0.062535 & 44 & 0.00094152 & 0.092059 \\
\hline 13 & 0.00098376 & 0.066137 & 45 & 0.00095392 & 0.093475 \\
\hline 14 & 0.00097463 & 0.060466 & 46 & 0.00098294 & 0.16889 \\
\hline 15 & 0.0009894 & 0.066149 & 47 & 0.00091436 & 0.21051 \\
\hline 16 & 0.00096761 & 0.060307 & 48 & 0.0009872 & 0.087814 \\
\hline 17 & 0.00099318 & 0.061169 & 49 & 0.00097482 & 0.079383 \\
\hline 18 & 0.00098608 & 0.060558 & 50 & 0.0009914 & 0.083805 \\
\hline 19 & 0.00098559 & 1,619444 & 51 & 0.00099636 & 0.082229 \\
\hline 20 & 0.00099137 & 0.247790 & 52 & 0.00099762 & 0.093336 \\
\hline 21 & 0.00099871 & 0.237830 & 53 & 0.00099978 & 0.093939 \\
\hline 22 & 0.00097806 & 0.229950 & 54 & 0.00098065 & 0.089639 \\
\hline 23 & 0.00097786 & 0.239740 & 55 & 0.00098517 & 0.093627 \\
\hline 24 & 0.00098336 & 0.228470 & 56 & 0.00097729 & 0.094889 \\
\hline 25 & 0.00099054 & 0.247880 & 57 & 0.00099427 & 0.093999 \\
\hline 26 & 0.00099186 & 0.236370 & 58 & 0.00099997 & 0.094864 \\
\hline 27 & 0.00099387 & 0.222930 & 59 & 0.00094152 & 0.092059 \\
\hline 28 & 0.00099789 & 0.085082 & 60 & 0.00095392 & 0.093475 \\
\hline 31 & 0.00098075 & 0.083942 & 61 & 0.00098294 & 0.16889 \\
\hline 32 & 0.00098265 & 0.083149 & 62 & 0.00091436 & 0.21051 \\
\hline
\end{tabular}


ANOXA(b)

\begin{tabular}{|c|c|c|c|c|c|c|}
\hline Model & & $\begin{array}{l}\text { Sum of } \\
\text { Squares }\end{array}$ & $d f$ & Mean Squgre & $F$ & Sig. \\
\hline \multirow[t]{3}{*}{1} & Regression & .457 & 1 & .457 & 35.221 & $.000(9)$ \\
\hline & Residual & .792 & 61 & .013 & & \\
\hline & Total" & 1.249 & 62 & & & \\
\hline
\end{tabular}

2. Predicters: (Constant), training

2. Deseodent Varigble: testing

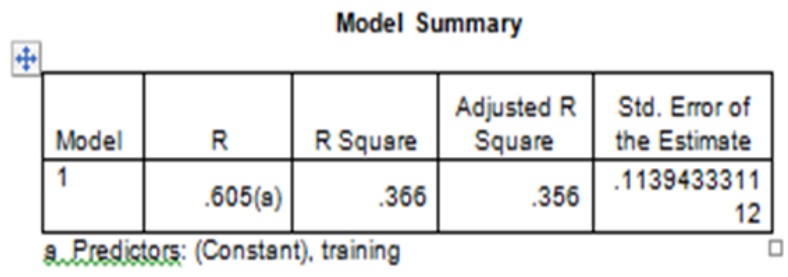

The contribution of the MSE (training) variable to MSE (testing) was $36.6 \%$. The remaining $63.4 \%$ was influenced by other variables outside the MSE (training) variable and to explain the effect of the MSE (training) variable on the MSE (testing) variable significantly affected because sig value $<0.05$, so the MSE (training) variable and the MSE (testing) variable have an effect in determining the accuracy of the Backpropagation method. Furthermore, obtained accuracy results based on the target value and the yield value from the predicted results of crude oil, can be explained based on the following SPSS 15.0 data processing:

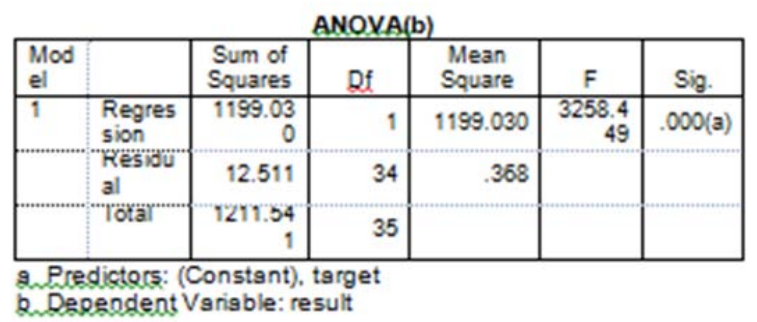

Model Summary

\begin{tabular}{|l|l|r|r|r|}
\hline Model & R & R Square & $\begin{array}{c}\text { Adjusted R } \\
\text { Square }\end{array}$ & $\begin{array}{r}\text { Std. Error of } \\
\text { the Estimate }\end{array}$ \\
\hline 1 & $.995(9)$ & .990 & .989 & .6066100489 \\
9
\end{tabular}

While the contribution of the target value variable to the outcome value variable is $99 \%$ while the remaining $1 \%$ is influenced by variables outside the target value variable, so that the target value variable has a very large contribution in determining the accuracy of the Backpropagation model, and the influence of the target value variable on the outcome value variable is significant because the sig value $<0.05$. Comparison between the target value and the result value can be seen in Figure 4.1.:



Figure 4.1. Graph of Target Value Comparison with Model Prediction Result Value

\section{Conclusion}

The conclusions that can be drawn from the research results are as follows: Training with the lowest MSE value in the prediction model is at the alpha training variable value of 0.5 , with 12 hidden neurons, 0.5 momentum, a maximum epoch of 10000 with an error tolerance of 0.001 . The resulting MSE training is 0.00087347 and MSE testing is 0.48477 . Furthermore, there is a significant influence between the target value variable on the predicted value variable and the $99 \%$ contribution of the target value variable to the yield value variable in determining the $83,6 \%$ accuracy by using the Backpropagation method.

\section{References}

[1]. Prambudia, Y., \& Nakano, M. (2012). Exploring Malaysia's transformation to net oil importer and oil import dependence. Energies, 5(8), 2989-3018.

[2]. Kementerian Energi dan Sumber Daya Mineral (KESDM). (2015). Handbook of Energy \& Economic Statistics of Indonesia. Jakarta.

[3]. Dewi, C., \& Muslikh, M. (2013). Perbandingan Akurasi Backpropagation Neural Network dan ANFIS Untuk Memprediksi Cuaca. Journal of Natural A, 1(1), 7-13.

[4]. Naik, A. R., \& Pathan, S. K. (2012). Weather classification and forecasting using back propagation feed-forward neural network. International journal of scientific and research publications, 2(12), 1-3.

[5]. Puspitaningrum, D. (2006). Pengantar Jaringan Syaraf Tiruan, Penerbit Andi, Yogyakarta.

[6]. Sutojo, T., Mulyanto, E., \& Suhartono, V. (2010). Kecerdasan Buatan, 2010. Yogyakarta: Penerbit Andi.

[7]. Jumarwanto, A., Hartanto, R., \& Prastiyanto, D. (2009). Aplikasi jaringan saraf tiruan backpropagation untuk memprediksi penyakit THT di Rumah Sakit Mardi Rahayu Kudus. Jurnal Teknik Elektro, 1(1), 11.

[8]. Anike, M. (2012). Pengembangan Sistem Jaringan Syaraf Tiruan Dalam Memprediksi Jumlah Dokter Keluarga Menggunakan Backpropagation (Studi Kasus: Regional X Cabang Palu)(Doctoral dissertation, UAJY).

[9]. Shofa, R. (2013). Prediksi Kebutuhan Air Pdam Berdasarkan Jumlah Pelanggan menggunakan AlAlaoui Backpropagation (Doctoral dissertation, Universitas Brawijaya). 